\title{
Observing the Effectiveness of Task Based Approach in Teaching Narrative Essay at a Private University
}

\author{
Hina Manzoor ${ }^{1}$, Sahar Azhar ${ }^{1} \&$ Fouzia Malik $^{1}$ \\ ${ }^{1}$ NED University of Engineering and Technology, Karachi, Pakistan \\ Correspondence: Hina Manzoor, NED University of Engineering and Technology, University Road, Karachi, \\ 75270, Pakistan. E-mail: eleganthina76@gmail.com
}

Received: December 3, 2019

Accepted: January 5, 2020 Online Published: February 5, 2020

doi:10.5539/ijel.v10n2p128

URL: https://doi.org/10.5539/ijel.v10n2p128

\begin{abstract}
Writing is one of the most challenging skills of English language. Learners in Pakistan seem unable to master this skill even after years of using English as an official/second language. The focus of this research was to prove that within task-based learning (TBL) framework, language learners engage in purposeful, problem-oriented, and outcome-driven tasks that yield much better results as compared to traditional teaching methods which often fail to generate the desired output. The aim of this research was to prove that Task Based Approach is quite effective and successful in teaching narrative essay writing with an only disadvantage of time consumption. This study resorted to semi-structured interviews and post-test for data collection targeting the undergraduate students in Pakistan. This action research used purposive sampling and employed qualitative research design since the data comprised of both; final drafts of narrative essays and open-ended interviews. The data collected in the post-task phase i.e. the narrative essays were assessed via writing assessment rubrics presented in the IELTS guide for the teachers (2015). The bands were awarded on the basis of four parameters: task achievement, cohesion and coherence, lexical resource, and grammatical range and accuracy. The results delineated that majority of students achieved 5 bands and an overall improvement was observed in the narrative writing skills of students. In the same stead, the students in interview presented the view that Task Based Approach was much more successful in teaching them narrative essay writing.
\end{abstract}

Keywords: task-based approach, narrative essay writing, task-based learning, task

\section{Introduction}

The treatment of English language within the Pakistani context evidently demonstrates its dominance and control (Rahman \& Sagar, 2015). A sound English learner must possess an equal ability in all skills of language; however, the skill of writing is one of immense importance, and demands a lot of endeavors on the part of the learner if one wishes to improve it. Also, teaching writing requires the employment of several distinct methodologies.

When compared with other fundamental skills such as listening, speaking and reading, writing is the most difficult skill because it requires writers to have a great deal of lexical and syntactic knowledge as well as principles of organization in L2 to produce a good writing (Tangpermpoon, 2008).

The absence of Task Based Approach from the canvas of English Language Teaching has led to a huge gap in transforming the classrooms into learner-centered. Within Task-Based Language Learning (TBLL), learning is cultivated through asking the learner to do a series of activities which finally leads to the accomplishment of the task. TBLL helps language learners get rid of learning language with a lack of context; instead it utilizes language as an instrument to perform real-world i.e. authentic tasks. While completing the task, the learner is forced to use language in the actual context, which grants authenticity to learning. By proving the effectiveness of Task Based Approach, this study will serve as a guideline for teachers to employ task-based approach in teaching narrative essay writing. Furthermore, it will also benefit students as the activities utilized in Task Based Approach are very interesting and helpful in developing creativity within learners. This study will also serve as a guideline for any researcher who wishes to pursue research on this topic along with curriculum designers since they can identify the advantages of Task Based Approach in teaching writing skills.

Kareem (2013) also highlighted writing as a complicated skill which has to operate in unison with numerous 
other language skills, like planning, organizing, etc. along with developing cognitive abilities in the learners. The design of a task-based lesson involves consideration of the stages or components of a lesson that has task as its principal component. These phases reflect the chronology of a task-based lesson i.e. the pre-task, the during-task and the post-task phase. However, only the during-task phase is obligatory in the task-based teaching. The rest of the two phases are only supportive in comparison, thus enabling the course instructor to judge the outcome of the task-based lesson. Thus, minimally a task-based lesson consists of the students just performing a task.

The last decennial of the 20th century led to the recognition of Task-Based Approach (TBA) within the domain of ELT. It became the focal point of research and grasped the attention of several eminent intellectuals leading to a large number of investigative studies (Sanchez, 2004). However, there is a noticeable gap of action research in this domain. There might be several reasons for this such as: the hardships in the using this approach within a classroom, the predicament in expanding the materials required for the implementation of this approach and a dearth of guides related to it. All of these factors collectively lead to the fact that TBA appears to be missing from the scene of English language learning and teaching.

In his other works, (Sanchez, 1992, 1997) has illustrated the fact that language teaching was previously based on two approaches i.e., grammatical approach and conversational approach. Both of them appeared to be in a state of constant tension with one another. On the other hand, TBA is not a secluded methodology in itself. Therefore, it can only be fully comprehended if viewed in comparison with the previous methods of communication. Thus, a little historical information is required to comprehend this approach.

Within Pakistan, a lack of task-based teaching is observed in general. For the last 70 years we have been teaching all the four skills of language via the traditional approach, even though the research demonstrates the effectiveness of task-based approach. The present study will be significant because there is a dearth of research on teaching narrative writing using TBLT approach. Also, teaching essay writing serves to be a challenge for the ELTs and this approach will ease the process of teachers' planning. Moreover, the research studies utilizing this approach were majorly focused on teaching generalized skills of writing and speaking through TBLT approach. Specifically, Narrative writing was not addressed in previous research studies at large. This generated a research gap for the researchers to conduct research in this arena.

This action research therefore, serves as a model for the educators in Pakistan that will elaborate the effects of the task-based approach on the students when they use it for learning writing. Furthermore, this research will also prove that task-based approach is extremely effective in teaching writing. Additionally, TBLT approach will also facilitate the teaching of other kinds of essays. It will also contribute as a sample for teaching narrative writing for the English language teachers (ELTs) and convince the policy makers, curriculum developers and syllabus designers to include this approach within the curriculum since it will be beneficial for both, teachers and students.

\subsection{Importance of Task Based Approach in Language Learning}

The 'Bangalore Project' (Prabhu, 1987) served as the basis of evolution of Task Based Approach. This project often utilizes the term 'task' which attributes to the specific type of acts performed within the classroom. Such acts were particularly fixated on the procedure of doing things (how) instead of placing the importance on content (what) as was mostly done in the techniques of teaching in that decennial. The main aim of this project was to cultivate grammatical competence along with enabling the learner to communicate effectively. Furthermore, it was also assumed that developing grammatical competence was dependent upon several 'internal self-regulating processes' which would later on support in delivering the meaning in 'favorable condition'. According to this project, the biggest duty of a language teacher was to develop such situations for the language learners which provide them with appropriate purposeful encounters. Henceforth, any binding of following a pre-prescribed formal syllabus was eliminated.

Vygotsky $(1962,1978)$ regards language as a happening triggered by the society. Language is in fact a social event via which an individual advances his skill while residing in the society. Thus, according to him, language is not the outcome of secluded learning; rather it is dependent on the social interactions. Furthermore, the ability to produce language is innate within the human brain for the sole purpose of communication with the exterior world. Every child distinctly builds their individual personalities via collaboration and contradiction with their surroundings and especially with other humans around them. Additionally, Vygotsky (1962) also believes that thought being completely distinct from language, only develops when interaction turns into monologue. Using monologue, children interact with themselves and develop their language skill and in the second phase they polish their communication skills via interaction with the society. Thus, in the light of Vygotskyan assumptions interaction is the basis of language learning since language is purely based on society. 
There is a wide difference in the practical and theoretical framework within Task Based Approach. The review of literature available on this subject reveals that TBA is dictated by very weak doctrines along with the fact that every individual defines TBA in view of a distinct yardstick. Furthermore, the implementation of TBA is distinct and varies according to every classroom and situation. Several scholars such as Prabhu (1987), Candlin (1987), Breen (1987), Longs and Crookes (1992), etc. have defined the word task in extremely distinct ways and the major question encompassing TBA appears to be if the differences amongst the researchers' perspectives are based on the fundamental differences within the tasks.

Tasks are truly defined in several different ways and in general they are illustrated to possess common characteristics. However, two prominent characteristics are highlighted which are closely linked with the proceedings of the project: the accomplishment of task and a thought process while carrying out the task. The activity itself granted the control of the classroom to the instructor raising a bug question on learners' autonomy which Prabhu (1987) focused on. Long (1985) described task in view of the daily activities performed by the people in real life; however, one needs to adapt these real-world tasks into the classroom environment where they are neither beneficial nor possible to carry out. Thus, the tasks performed within a classroom need to be 'pedagogic' in nature and Nunan (1989) proposed such a definition of task which is much fixated on the classroom of language:

"A piece of classroom work which involves learners in comprehending, manipulating, producing or interaction in the target language; while their attention is principally focused on meaning rather than form" (Nunan, 1989, p. $10)$.

Thus, the different definitions of task presented by different researchers show that there are many outlooks to this issue. Furthermore, this difference in opinion amongst the intellectuals may be because every individual is looking at task from their own distinct prior concepts regarding the language teaching methodology. This results in defining the object of study in a different way leading to distinct outcomes.

The real-world tasks and pedagogic tasks are not to be likened; the ones carried out in real world situations are mostly not transferable to the pedagogical scenarios due to the lack of situational settings commonly available in the real word. Therefore, in a language classroom the points of focus are the activities that help in developing linguistic communication whether oral or written.

In Pakistan, writing pedagogy is sharply and noticeably endangered because of many advocates. This danger is caused majorly due to the lack of available resources for teachers and students, scarcity of proficient teachers, overburdened classrooms along with the utilization of conventional methodology for teaching writing of English Language (Zaki, Rashidi, \& Kazmi, 2013). Therefore, there is a dire need of alternative strategies which might serve to be beneficial for the learners as well as teachers. One of such models is Task Based Approach also referred to as Task Based Language Teaching (TBLT) when practiced within a language classroom. In the same stead, Ahmed and Bidin (2016) justified the use of TBLT showing that its utilization in an English language classroom enhances the writing skills of ESL learners to a great degree. This research study deems to answer the following research questions:

Q1. What are the perceptions of intermediate learners towards TBLT approach?

Q2. Does task-based language teaching approach serve to be more effective or appropriate for teaching narrative writing in English language?

\subsection{Literature Review}

No practical implementation of Task based approach appears within the Pakistani educational context. The traditional notions of syllabus are utilized for delivering content and the pedagogical approaches are still in the traditional phase. Therefore, task-based syllabus can play an important role in developing students' Knowledge about Language (KAL).

\subsubsection{Task}

Task based approach is still undergoing a controversial debate regarding its uniformity and practice. Breen (1987) declared task-based approach as being process-oriented. He further stated that going through the complete process ensures the achievement of objectives. In contrast, Long and Crookes (1992) discussed three types of task-based syllabus in their study: the procedural syllabus, process syllabus and the task syllabus. The definition of the term task in literature has been given by several (Prabu, 1987; Bygate, 2001; Ellis, 2000, 2003; Lee, 2000; Long, 1985, 1991, 1997, 2005; Nunan, 2004; Richards \& Rodgers, 2001; Salaberry, 2001; Skehan, 1998a, 1998b, 2003; Willis, 1996a, 1996b, 1998). A few simple definitions are as under: 
Wills (1996) said, "Tasks are always activities where the target language is used by the learner for a communicative purpose (goal) in order to achieve an outcome" (p. 23).

Ellis (2003) expounded "A task requires personal information to be exchanged, or a problem to be solved, or a collective judgment to be made and bears a relationship to things that happen outside the classroom" (p. 38).

In a nutshell, task is an activity designed for a specific purpose or construct in teaching. Its aim is to achieve the objectives effectively within a small span of time. It enables the student to get better understanding of the taught content via organized stages.

\subsubsection{Framework of the Task-based Approach}

A task-based approach is a learner centered approach in which the teacher works as a facilitator rather than an authoritarian and creates a conducive learning environment for the students. Nunan (2006) mentioned five characteristics of the task-based approach in his study:

1) Meaning is primary.

2) Learners are not provided with restated activities.

3) There is some relevant relationship to real-world activities in it.

4) The completion of task has major considerations.

5) The achievement of the outcomes is assessed through given tasks.

While implementation of a task-based approach, the topics are designed by the instructors and are based on needs and expectations of learners. They also incorporate the learning goals. Willis (1996) emphasized on the selection of such types of tasks as an activity for teaching i.e., listing, matching, ordering/sorting, comparing/ contrasting, problem solving, sharing personal experiences and other creative tasks/projects.

The topic selected for teaching students was constructed under 3 phases. Following table provides a brief picture of the plan:

Table 1. Willis' J. (1996) TBLT framework

\begin{tabular}{|c|c|c|}
\hline Phase & Purpose & Examples \\
\hline Pre-task & $\begin{array}{l}\text { Introduce the topic and prepare students to } \\
\text { perform the task }\end{array}$ & $\begin{array}{l}\text { Observe model of the task } \\
\text { Activate topic schema } \\
\text { Task planning opportunity }\end{array}$ \\
\hline During Task & Undertake and execute the actual task & $\begin{array}{l}\text { Provide students data needed to complete the task } \\
\text { Instructor monitoring of student performance }\end{array}$ \\
\hline Post-task & $\begin{array}{l}\text { Opportunity to repeat or expand task } \\
\text { Allow reflection of task }\end{array}$ & $\begin{array}{l}\text { Student presentation and other public performances of task } \\
\text { Report summarizing task outcomes }\end{array}$ \\
\hline
\end{tabular}

Adopted from "Task-based language teaching and learning: An overview", Oxford, R. L. (2006, p. 20). Asian EFL Journal.

In the recent years' research has sparked interest towards task-based language learning and teaching (Willis, 1996; Skehan, 1996, 1998; Bygate, Skehan, \& Swain, 2000; Ellis, 2000, 2006). All the aforementioned studies have been carried out in different Asian and Western contexts. Wills (1996) presented a three-step sequence of Task- based approach for addressing underlying TBT principles. Additionally, Skehen $(1996,1998)$ explored pedagogical structure and future dimensions of TBA and Ellis (2006) elaborated the utilization of tasks in TBA within actual lesson plans. This study also explained how this pedagogical competency can be utilized by language teachers.

Likewise, Sofia (2013) incorporated TBL approach in teaching technical writing to engineering students, which resulted in enhanced writing skills of students. Similarly, Narjeed and Sayyed (2013) identified the pre-task step of this approach as an effective strategy for developing writing ability while accomplishing personal or decision-making tasks among EFL learners. On the contrary, Linglay (2006) found that the same approach has limited practice within the Canadian context.

\subsubsection{Modes of Writing}

Writing among other skills of language is considered as the most challenging in terms of adoption or adaption. Kim and Kim (2005) researched that EFL learners mostly face "time constraints in learning writing" (p. 68). In 
Pakistan, the students are facing the same problem. The curricula of schools and colleges have a long history of practicing traditional language teaching methods. Many genres are being practiced at different levels of education for a long time (Blicblau, Mc Manus, \& Prince, 2009) but no positive outcome is observed.

Devitt (2008) defined genres as the ways of communication, meeting expectations and saving time. Genres refer to different modes of writings and are broadly classified into four types; descriptive, narrative, expository and argumentative (Connor, 1996; Richards \& Schmidt, 2002). This paper inculcates and discusses the application of TBLT approach in teaching narrative writing.

\subsubsection{Narrative Writing}

It is accepted as the most famous and simplest among the writing modes. Richards and Schmidt (2002) defined "narrative writing reports an event or tells the story of something that happened" (p. 337). This writing type entertains, excites and at times becomes informative for the readers. In addition, "Narrative text depicts events, actions, emotions, or situations the people in a culture experience" (Graesser, Golding, \& Long, 1991, mentioned in Dickson et al., 2007). Thus, the events are organized and presented to the readers in such a way that they seem real and take the reader into the world of imagination. Moreover, Jewell (2004) presented the most extensive definition for narrative writing:

"Narration" or a "narrative" is a detailed description of events. It represents the list of events in sequence written in the form of a paragraph. The purpose of narrative writing is not to demonstrate any cause and effect; it only exhibits what happened and in which order" (p. 4).

\subsubsection{Recent Research Studies Related to Narrative Writing and TBLT}

The use of TBLT for teaching language skills such as writing and speaking is common in the research arena. Narrative writing teaching has been focused by several researchers throughout the world both within the international and Pakistani context. A few of these studies have been illustrated in the table below:

Table 2. Recent studies related to TBLT around the world

\begin{tabular}{|c|c|c|c|c|c|}
\hline Researcher & Year & Topic/Purpose of Study & Method and Tools & Population/ Sample & Findings \\
\hline $\begin{array}{l}\text { Karim, } \\
\text { Husain and } \\
\text { Weda }\end{array}$ & 2014 & $\begin{array}{l}\text { To find whether or not the } \\
\text { implementation of TBLT } \\
\text { improves the students' } \\
\text { ability in writing narrative } \\
\text { text (p. 63) }\end{array}$ & $\begin{array}{l}\text { Quasi-experiment } \\
\text { al research } \\
\text { design; } \\
\text { writing test; } \\
\text { questionnaire (p. } \\
66)\end{array}$ & $\begin{array}{l}66 \text { first year students } \\
\text { (class X) of SMAN } 2 \\
\text { Bantaeng (p. 66) }\end{array}$ & $\begin{array}{l}\text { The students' ability in writing } \\
\text { narrative text improved within } \\
\text { the experimental group who were } \\
\text { treated using TBLT approach (p. } \\
63 \text { ) }\end{array}$ \\
\hline $\begin{array}{l}\text { Kafipour, } \\
\text { Mahmoudi } \\
\text { and } \\
\text { Khojasteh }\end{array}$ & 2018 & $\begin{array}{l}\text { To examine the impacts of } \\
\text { utilizing task-based writing } \\
\text { instruction on Iranian EFL } \\
\text { learners' writing } \\
\text { competence (p. 1) }\end{array}$ & $\begin{array}{l}\text { Quantitative } \\
\text { experimental } \\
\text { method; } \\
\text { Oxford Quick } \\
\text { Placement Test; } \\
\text { Two TOEFL } \\
\text { based comparable } \\
\text { writing tests (p. } \\
6 \text { ) }\end{array}$ & $\begin{array}{l}80 \text { Iranian learners } \\
\text { (male and female) } \\
\text { studying English as a } \\
\text { foreign } \\
\text { language at the } \\
\text { intermediate level (p. } \\
6 \text { ) }\end{array}$ & $\begin{array}{l}\text { Significant improvements were } \\
\text { observed in the writing ability of } \\
\text { the Iranian EFL learners who } \\
\text { practiced writing skills using } \\
\text { task-based language } \\
\text { teaching techniques (p. 1) }\end{array}$ \\
\hline $\begin{array}{l}\text { Birjandi and } \\
\text { Malmir }\end{array}$ & 2011 & $\begin{array}{l}\text { To discover the impact of } \\
\text { task-based approach } \\
\text { Vs. traditional approach on } \\
\text { the narrative and } \\
\text { expository writing of the } \\
\text { Iranian EFL learners (p. 1) }\end{array}$ & $\begin{array}{l}\text { Quasi-experiment } \\
\text { al research } \\
\text { design; } \\
\text { TOEFL test- } \\
\text { A writing } \\
\text { pre-test; } \\
\text { A narrative } \\
\text { writing post-test } \\
\text { (p. } 1-2)\end{array}$ & $\begin{array}{l}120 \text { students from } \\
\text { Iranian junior and } \\
\text { senior EFL learners } \\
\text { studying English } \\
\text { Language Translation } \\
\text { at Islamic Azad } \\
\text { University of } \\
\text { Hamedan (p. } 7 \text { ) }\end{array}$ & $\begin{array}{l}\text { Teaching narrative and } \\
\text { expository writing through TBA } \\
\text { is more efficacious than teaching } \\
\text { them via the traditional approach } \\
\text { (p. } 1-2)\end{array}$ \\
\hline $\begin{array}{l}\text { Akil, Jafar } \\
\text { and Halim }\end{array}$ & 2018 & $\begin{array}{l}\text { To establish the learners' } \\
\text { response to the } \\
\text { implementation of TBA in } \\
\text { improving students writing } \\
\text { performance (p. 27) }\end{array}$ & $\begin{array}{l}\text { Case Study; } \\
\text { Observation; } \\
\text { questionnaire; } \\
\text { documentation (p. } \\
27 \text { ) }\end{array}$ & $\begin{array}{l}29 \text { students of tourism } \\
\text { management in } \\
\text { Polytechnic of } \\
\text { Makassar registered in } \\
2015 / 2016 \text { (p. 29) }\end{array}$ & $\begin{array}{l}\text { The students' response towards } \\
\text { the implementation of task-based } \\
\text { teaching in enhancing students' } \\
\text { writing performance were } \\
\text { extremely good (p. } 32 \text { ) }\end{array}$ \\
\hline
\end{tabular}




\begin{tabular}{|c|c|c|c|c|c|}
\hline Researcher & Year & Topic/Purpose of Study & Method and Tools & Population/ Sample & Findings \\
\hline Ahmed & 2018 & $\begin{array}{l}\text { To evaluate the impact of } \\
\text { TBLT in enhancing writing } \\
\text { and speaking skills of } \\
\text { Pakistani undergraduates } \\
\text { (p. iii) }\end{array}$ & $\begin{array}{l}\text { Quasi-experiment } \\
\text { al research } \\
\text { design; } \\
\text { Tests (pre-test } \\
\text { and post-test); } \\
\text { Reflective } \\
\text { Journals (p. iii) }\end{array}$ & $\begin{array}{l}50 \text { Pakistani ESL } \\
\text { learners at } \\
\text { undergraduate level } \\
\text { enrolled in } \\
\text { Environmental } \\
\text { Sciences and Business } \\
\text { Administration (p. } \\
142 \text { ) }\end{array}$ & $\begin{array}{l}\text { The performance of experimental } \\
\text { group was better than the control } \\
\text { group in L2 writing and speaking } \\
\text { and it was deduced that TBLT } \\
\text { improved L2 writing and } \\
\text { speaking skills (p. iii) }\end{array}$ \\
\hline Rashid & 2017 & $\begin{array}{l}\text { To evaluate the efficacy } \\
\text { TBLT in enhancing master } \\
\text { level students' narrative } \\
\text { writing skill along with } \\
\text { their beliefs regarding } \\
\text { TBLT (p. 20) }\end{array}$ & $\begin{array}{l}\text { Quasi-experiment } \\
\text { al research } \\
\text { design; } \\
\text { Tests (pre-test } \\
\text { and post-test); } \\
\text { Perception } \\
\text { Questionnaires } \\
\text { (p. 23) }\end{array}$ & $\begin{array}{l}122 \text { students in seven } \\
\text { different Government } \\
\text { and Private Institutes } \\
\text { in tehsil } \\
\text { Rahim Yar Khan (p. } \\
\text { 22) }\end{array}$ & $\begin{array}{l}\text { Highly significant difference was } \\
\text { seen among the two groups. The } \\
\text { treatment groups' general } \\
\text { perception towards TBLT was } \\
\text { positive (p. 20) }\end{array}$ \\
\hline Prasetyawati & 2017 & $\begin{array}{l}\text { The implementation of } \\
\text { teaching narrative text by } \\
\text { using task-based instruction } \\
\text { and the students' } \\
\text { difficulties in } \\
\text { writing narrative text (p. } \\
\text { xii) }\end{array}$ & $\begin{array}{l}\text { Descriptive } \\
\text { qualitative } \\
\text { research method; } \\
\text { Observation; } \\
\text { questionnaire; } \\
\text { Interview }\end{array}$ & $\begin{array}{l}\text { VIII Grade } \\
\text { Students } \\
\text { Of SMP } \\
\text { Muhammadiyah } 1 \\
\text { Gatak in the year } \\
2015 / 2016\end{array}$ & $\begin{array}{l}\text { The implementation of teaching } \\
\text { writing } \\
\text { narrative text using TBI was well } \\
\text { conducted } \\
\text { and the written works of students } \\
\text { were well organized. However. } \\
\text { the students faced difficulties in } \\
\text { finding the meaning of a text and } \\
\text { were unfamiliar with past tense } \\
\text { (p. xii) }\end{array}$ \\
\hline $\begin{array}{l}\text { Pragasam, } \\
\text { Singh, Singh, } \\
\text { Mostafa, } \\
\text { Ja'afar, } \\
\text { Abdullah, } \\
\text { Zulkepli and } \\
\text { Khaja }\end{array}$ & 2018 & $\begin{array}{l}\text { Inspecting whether } \\
\text { Task-based learning (TBL) } \\
\text { can enhance narrative } \\
\text { writing composition among } \\
\text { form four students. (p. 49) }\end{array}$ & $\begin{array}{l}\text { Action research; } \\
\text { Observation; } \\
\text { Reflective } \\
\text { journal; } \\
\text { Semi-structured } \\
\text { interview; } \\
\text { Documents (p. } \\
\text { 49) }\end{array}$ & $\begin{array}{l}10 \text { Form Four } \\
\text { students from a school } \\
\text { situated in the rural } \\
\text { area (p. 52) }\end{array}$ & $\begin{array}{l}\text { The students performed well in } \\
\text { TBL Lesson as compared to other } \\
\text { lessons and perceived it helpful } \\
\text { in teaching narrative writing skill } \\
\text { and reflected positive responses. } \\
\text { Also, task-based learning } \\
\text { improved students' performance } \\
\text { in narrative writing (p. 49) }\end{array}$ \\
\hline Kadel & 2013 & $\begin{array}{l}\text { To discover } \\
\text { the effectiveness of TBLT } \\
\text { in developing writing skills } \\
\text { of secondary level learners } \\
\text { in Nepal (p. iv) }\end{array}$ & $\begin{array}{l}\text { Quasi- } \\
\text { experimental } \\
\text { research design; } \\
\text { textbook analysis, } \\
\text { Tests (pre-test } \\
\text { and post-test), } \\
\text { and intervention } \\
\text { tasks for writing } \\
\text { skills (p. 177) }\end{array}$ & $\begin{array}{l}50 \text { students (male and } \\
\text { female) of Grade } 9 \\
\text { from two schools (p. } \\
176 \text { ) }\end{array}$ & $\begin{array}{l}\text { The use of TBLT in developing } \\
\text { writing skills in English has been } \\
\text { proved } \\
\text { successful since experimental } \\
\text { group showed significant } \\
\text { improvement in the post test (p. } \\
\text { 269) }\end{array}$ \\
\hline $\begin{array}{l}\text { Ahmed, and } \\
\text { Bidin }\end{array}$ & 2016 & $\begin{array}{l}\text { to ascertain the efficacy of } \\
\text { TBLT in } \\
\text { improving writing skills of } \\
\text { the university } \\
\text { undergraduates learning } \\
\text { English language at the } \\
\text { language centers in } \\
\text { the public sector } \\
\text { institutions of tertiary level } \\
\text { in Malaysia (p. 208) }\end{array}$ & $\begin{array}{l}\text { Quasi- } \\
\text { experimental } \\
\text { research design; } \\
\text { Tests (pre-test } \\
\text { and post-test) (p. } \\
212)\end{array}$ & $\begin{array}{l}30 \text { International } \\
\text { students from } \\
\text { different nations all } \\
\text { part of the } \\
\text { expanding circle in } \\
\text { the Kachru's (1990) } \\
\text { three concentric } \\
\text { circles (p. 211) }\end{array}$ & $\begin{array}{l}\text { The experimental group } \\
\text { performed expansively better } \\
\text { than the control group in their L2 } \\
\text { writing skill since there were no } \\
\text { significant differences to } \\
\text { mark any improvement in the } \\
\text { scores of control group during } \\
\text { pretest and posttest in their } \\
\text { writing skills (p. 214) }\end{array}$ \\
\hline
\end{tabular}

\section{Method}

\subsection{Research Design}

Bogdan and Biklen (2006) describe qualitative research as one which "seeks to grasp processes by which people construct meaning and to describe what those meanings are" (p. 43). Under this approach, the current research study follows action research design which was presented in 1940s by Kurt Lewin. Action research is an 
investigation in the direction of an instructor's job and their learners' learning within the classroom setting (Feldman \& Mintsrel, 2000). Also, "Action research implies no specific methods of inquiry. Methods are context-bound and will be operationally shaped in the light of the problems that are presented in the context. Action research has no distinctive methodological characteristics..." (Elliott, 2005, p. 370). A lot of researches in this domain have adopted experimental research design however, the present study employed action research as one of the researchers was the course instructor and additionally had to teach narrative essay (as part of the syllabus). The students also demonstrated poor performance in descriptive writing lessons taught earlier. Therefore, the researcher decided to implement a different strategy for teaching narrative writing in the classroom. The following research study was carried out via TBA in a cycle of a) Planning) Action and c) Fact finding. Students were taught Narrative essays by using task-based approach and at the last stage their writing was assessed on the basis of IELTS writing assessment criteria.

\subsection{Population}

The population of this study comprised of undergraduate female students from a private university in Karachi. The students were registered in a 4-year degree program i.e., Bachelors of Science in Bio-Chemistry from the Faculty of Science in a public university.

\subsection{Sample}

Purposive sampling technique was used for the collection of data for this research and a specific classroom under the guidance of the researcher (as the course teacher) was selected for this purpose. Purposive sampling is a useful technique through which essential data is collected for specific setting, persons and events that cannot be accomplished by any other source (Maxwell, 1996).

The sample of this study consisted of 38 undergraduate second year female students of Bachelors of Science registered in course English C-IV during fall 2017. The learners' age group varied from 18 to 21 years with diverse cultural, linguistic and ethnic backgrounds. Also, the learners had experienced distinct mediums of instruction during their previous education i.e. English and Urdu. They had also studied three compulsory courses of English language at the university prior to this research study.

\subsection{Instruments}

Data was collected in the form of narrative essays after conducting a series of tasks from the undergraduate students in the researcher's classroom. It was analyzed and evaluated through IELTS writing rubrics and the scores were assigned as per the given scoring criteria of IELTS. Triangulation was done through open ended interviews from five students to validate the collected data.

\subsection{The Application of Task-Based Approach in the Classroom}

\subsubsection{Pre-Task Stage}

The lesson was planned and the basic Narrative essay writing elements were taught through power point presentation. In the first stage, task number 1 (Appendix A) was administered. It was based on a two-picture handout and the students had to determine and establish characters, plot, problem, climax, resolution and construct a thesis statement based on the problem they had assumed. The time allotted for this activity was 50 minutes since this was the duration of a period at the institution

\subsubsection{While-Task Stage}

In the while task stage, task 2 (Appendix B) was carried out. For this purpose, a prompt was provided and the students were asked to write a story based on the problem. The aim of this second attempt was to polish the students' skills and transform them into independent narrative writers. The time given for this activity was also similar to the previous task i.e. 50 minutes.

\subsubsection{Post-Task stage}

Task No. 3 (Appendix C) was based on a test of writing a narrative essay in the class. At this stage, the learners were asked to complete the task independently without any support from the teacher. The duration of 50 minutes was again given to them for the completion of the assigned task. 


\section{Results}

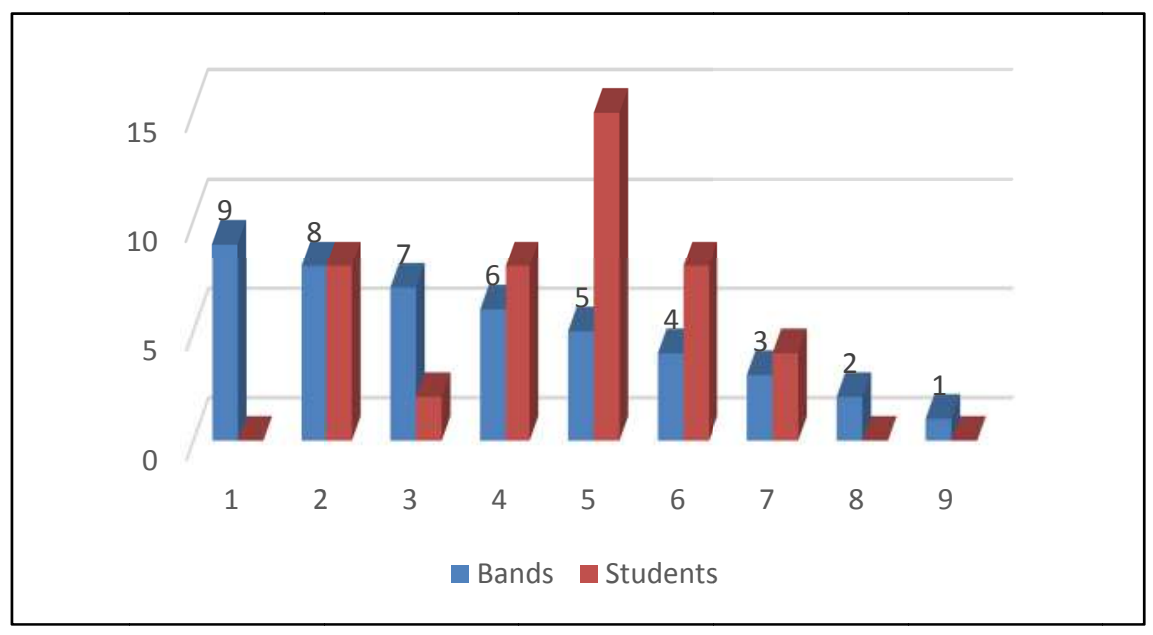

Figure 1. Bands to students' ratio

The data collected in the post-task phase i.e., the narrative essays written by the students were assessed using the criteria of writing assessment rubrics presented in the guide for the teachers published by IELTS in the year 2015 . The 9 bands mentioned in the writing assessment rubrics were awarded on the basis of four parameters: task achievement, cohesion and coherence, lexical resource, and grammatical range and accuracy.

Only one student scored 9 bands in the post test and she was an effective user of English language. Very few (unsystematic) errors were observed in her essay and she utilized appropriate and necessary vocabulary. Additionally, her writing also had the ability to deal with complex situations.

Likewise, two students scored 7 bands in the post test and appeared to be good users of English language. However, they were affected by occasional inaccuracy, misinterpretation and unsuitable vocabulary. Furthermore, they demonstrated the ability of using the complex language structures fairly well and possessed a sense of detailed argumentation.

In the same stead, eight students secured a score of 6 bands in the writing task and were regarded as average users of English language. Their writing showed an effective skill along with a few mistakes, unsuitable words and misinterpretations in certain contexts. The use of complex structures of English language was seen in the essay but was limited to common situations.

Moreover, fifteen students scored 5 bands in the post-task and were regarded as modest users of English language. Their writings showed a limited command of English, since they were majorly unable to deal with complex language structures. However, the use of English in ordinary situations was a lot better.

In addition, eight students secured a score of 4 bands in narrative essay writing task and appeared to be limited users of English language. Their basic competence appeared to be restricted to common situations and certain issues were seen in comprehension and verbalization. Also, the use of complex language was completely missing from the writing.

Apart from this, four students scored 3 bands in the post task and were regarded as extremely limited users of English language. Their writing depicted the ability to communicate and understand only common meanings, strictly limited to commonplace situations. Recurring breakdowns were also evident in their communication.

For triangulating the result, an interview was conducted from five participants who were selected randomly from the class. Each participant answered a set of 4 questions and their responses were utilized for generating the following themes.

\subsection{Perception Regarding Teaching Approach}

The first question was about the difference between experiencing the traditional style of teaching essay writing and teaching essay writing through Task Based Approach. Majority of the students presented the view that Task Based Approach was much more successful in teaching them essay writing since it was based on step by step 
skill development unlike the traditional essay writing, which cultivates the entire skill at once.

\subsection{Effectiveness of TBA}

The second question was focused on the effectiveness of Task based Approach within the classroom. All the participants agreed with the fact that their amount of learning drastically increased as a result of implementing TBA in class. The participants also asserted that they were previously unaware of the fact that English language writing expertise could be attained so smoothly.

\subsection{Notion Towards the Utilization of Innovative Activities}

The third question was about the activities used for TBA in class. Most of the students found the tasks interesting and beneficial for learning narrative essay writing. Furthermore, the participants illustrated that step-by-step progression towards the actual goal made the ordeal of acquiring language much easier for them.

\subsection{Issues encountered while implementation of TBA}

The fourth question was related to the issues learners faced while using Task Based Approach. In response to this, the participants highlighted the fact that this approach took more time and they were initially unable to deal with the topic provided to them in the post-task phase. This was because they were unable to start writing the essay only with a topic.

\section{Discussion}

This study aspired to check the effectiveness of TBLT approach in teaching narrative writing within English language. The results depicted that an overall improvement was observed in the writing skills of the students in the light of the writing rubric adopted for the study. Learners' narrative writing skills were evaluated through IELTS writing assessing criteria task 1 (see appendix D). Four major criteria of IELTS writing were task response, coherence and cohesion, lexical resources and grammatical range and accuracy. The errors in written responses were marked by following codes (see Appendix E)

Table 3. Error codes

\begin{tabular}{ll}
\hline Errors & Codes \\
\hline Spellings & $\mathrm{Sp}$ \\
Structure & $\mathrm{St}$ \\
Grammar & $\mathrm{Gr}$ \\
Coherence & $\mathrm{Coh}$ \\
Lexical Resource & $\mathrm{Lr}$ \\
\hline
\end{tabular}

The sample size for the study was 38 students and the procedure was based on three tasks in total. Majority of the students $(\mathrm{n}=15)$ secured 5 bands which highlights that overall learners were average in terms of narrative writing. A considerable number of students $(\mathrm{n}=8)$ scored 6 bands whereas a few students $(\mathrm{n}=8)$ gained 4 bands. Similarly, a small number of students $(n=3)$ acquired a very low score i.e. 3 bands. On the contrary, two students attained 7 bands and only one student was able to obtain 9 bands which was an extraordinary performance.

Likewise, the study also aimed to identify the perceptions of intermediate learners towards TBLT approach. The interviews highlighted the students' perception that TBLT technique served to be more successful than the traditional method of teaching essay writing. This was because the TBLT taught narrative essay writing in three steps i.e. via three tasks, unlike the traditional approach which develops the writing skill in a stead. The participants also illuminated that the implementation of Task Based Approach within the classroom led to an immense maximization in the degree of learning narrative writing. The inclusion of innovative and captivating tasks within TBA was also highly appreciated by the respondents since the gradual development of writing skills made language learning simpler. Contrarily, the last question of the interview enlightened the issues encountered by the students during the practice of TBA. In their view, this approach was more time-consuming and was unable to cultivate autonomy in terms of narrative writing.

In a nutshell, an overall improvement in narrative writing was observed by the researcher. Secondly, consistent use of tasks led the learners to become better writers. Regardless of the time constrains and less awareness of TBLT, learners showed great interest while practicing narrative writing via a variety of tasks. Their perception towards TBLT was highly positive and in the course of time they discovered it to be a more effective, systematic and organized approach. Therefore, this teaching strategy could and should be practiced with other topics or themes. Skehan (1996), Carless, (2009), Ellis (2009) and Akil, Jafar, and Halim (2018) also underpinned the 
effectiveness of TBLT in their research studies, which support the outcomes of this research. Likewise, Ahmed (2018) conducted an experimental research on TBLT in Pakistan and revealed that the experimental group performed better than control group. In the same stead, Tabari (2019) investigated task-based approach on two groups and found that structured tasks in classrooms effectively influenced the syntactic complexity, lexical complexity, and accuracy of L2 writing. Ratnawati (2019) in his mixed method research aimed to find the effectiveness of TBL approach in teaching writing skill at State Vocational School in Bone and found major improvement in students' writing via the calculation of mean scores which increased from 34.83 in pre-test to 56.17 in post-test.

The responses of students during interview also favored the effectiveness of TBLT approach in teaching narrative writing since it evoked more interest as compared to conventional methods. However, it is to be made a characteristic part of the narrative writing lesson plans. This in turn, will aid in dealing with the time constraints presented by TBA (as highlighted in the study). Rubaiat (2018) researched to find out the impact of TBLT in enhancement of students' reading and writing skills through survey questionnaire and classroom observation checklist. In this study the students and teachers showed positive attitude towards TBLT and shared that TBLT played an effective role in developing their writing skills which was similar to the study findings.

Even though this study focused on the application of TBLT in teaching narrative writing, however, this strategy might and should be implemented in teaching other disciplines or domains as well to cope up with the new practices. TBLT is time consuming and poses difficulty while practice, hence, professional development trainings should be conducted for the teachers for dealing with the current and future pedagogical challenges. Curriculum developers should also re-design the course content to create harmony among TBLT and language learning syllabi.

Similar studies should be carried out on students of other schools, colleges or universities to determine whether any similarities exist within the findings or to ascertain the perceptions of other students towards this approach. Additionally, more research studies following different research designs and methodologies could also be useful in exploring the difference between findings. This in turn, will also increase the reliability and validity of the TBLT approach.

\section{References}

Abdi, T. M. (2019). Differential Effects of Strategic Planning and Task Structure on L2 Writing Outcomes. Reading \& Writing Quarterly, 1-19. https://doi.org/10.1080/10573569.2019.1637310

Ahmed, R. Z. (2018). The effect of task-based language teaching on improving the writing and speaking skills of Pakistani ESL learners. Doctoral dissertation, Universiti Utara Malaysia. Retrieved from http://etd.uum.edu.my/id/eprint/7399

Ahmed, R. Z., \& Bidin, S. J. B. (2016). The Effect of Task Based Language Teaching on Writing Skills of EFL Learners in Malaysia. Open Journal of Modern Linguistics, 6(03), 207. https://doi.org/10.4236/ojml.2016.63022

Akil, M. Y., Jafar, M. B., \& Halim, A. (2018). Task Based Language Teaching for Writing of the Students in Indonesian Tourism Polytechnics (A Case Study of the Fourth Semester Students at Tourism) Management of Polytechnic of Makasar. Journal of Humanities and Social Science, 23, $27-34$.

Al Khalili, S. A. H. (n.d.). TBLT in the Omani Classroom. Faculty of Education, 379.

Azizzadeh, L., \& Dobakhti, L. (2015). The Effect of Task Repetition on Complexity and Accuracy of Iranian High-intermediate EFL Learners' Narrative Writing Performance. International Journal of Applied Linguistics and English Literature, 4(2), 17-25. https://doi.org/10.7575/aiac.ijalel.v.4n.2p.17

Birjandi, P., \& Malmir, A. (2011). The effect of task-based approach on the Iranian advanced EFL learners' narrative vs. expository writing. Iranian Journal of Applied Language Studies, 1(2), 1-26.

Blicblau, A. S., McManus, K. J., \& Prince, A. (2009). Developing writing skills for graduate NESBC students. The Reading Matrix, 9(2), 198-210. Retrieved from https://pdfs.semanticscholar.org/7f6d/fe90b555a1e7a362fe50f163e2c45044717f.pdf

Bogdan, R. C., \& Biklen, S. K. (2006). Qualitative Research in Education: An Introduction to Theory and Methods. Allyn \& Bacon. Retrieved https://en.wikipedia.org/wiki/Special:BookSources/9780205512256

Breen, M. P. (1987a). Learner contributions to task design. In C. N. Candlin \& D. Murphy (Eds.), Luncaster Practical Papers in English Language Education (Vol. 7: Language Learning Tasks, pp. 23-46). 
Englewood Cliffs, NJ: Prentice Hall.

Bygate, M., Skehan, P., \& Swain, M. (Eds.). (2001). Researching Pedagogic Tasks: Second Language Learning, Teaching, and Testing. London, England: Longman.

Candlin, C. N. (1987). Towards task-based language learning. In C. N. Candlin \& Murphy (Eds.), Lancaster Practical Papers in English Language Education (Vol. 7, Language Learning Tasks, pp. 5-22). Eaglewood Cliffs, NJ: Prentice Hall.

Carless, D. (2009). Revisiting the TBLT versus P-P-P debate: Voices from Hong Kong. Asian Journal of English Language Teaching, 19, 49-66. Retrieved from http://citeseerx.ist.psu.edu/viewdoc/download?doi=10.1.1.707.9280\&rep=rep1\&type=pdf

Connor, U. (1988). Research frontiers in writing analysis. In T. Silva \& P. K. Matsuda (Eds.), Landmark Essays on ESL Writing (PP. 75-90). Mahwah, NJ: Erlbaum.

Connor, U. (1996). Contrastive Rhetoric: Cross-Cultural Aspects of Second-Language Writing. Cambridge: Cambridge University Press. https://doi.org/10.1017/CBO9781139524599

Dickson, A., Knussen, C., \& Flowers, P. (2007). Stigma and the delegitimation experience: An interpretative phenomenological analysis of people living with chronic fatigue syndrome. Psychology \& Health, 22(7), 851-867. https://doi.org/10.1080/14768320600976224

Elliott, J. (2005). Becoming critical: The failure to connect. Educational Action Research, 13(3), 359-374. https://doi.org/10.1080/09650790500200297

Ellis, R. (2000). Task-Based Research and Language Pedagogy. Language Teaching Research, 4, 193-220. https://doi.org/10.1177/136216880000400302

Ellis, R. (2003). Task-Based Language Teaching and Learning. Oxford, UK: Oxford University Press.

Ellis, R. (2006). Principles of Task Based Teaching. Paper presented at the 2006 Asian EFL Journal Conference, Pusan, Korea.

Ellis, R. (2009). Task - based language teaching: Sorting out the misunderstandings. International Journal of Applied Linguistics, 19(3), 221-246. https://doi.org/10.1111/j.1473-4192.2009.00231.x

Feldman, A., \& Minstrel, J. (2000). Action research as a research methodology for study of teaching and learning science. Handbook of research design in mathematics and science education (pp. 429-455). Mahwah, NJ: Lawrence Erlbaum.

Foster, P., \& Skehan, P. (1996). The influence of planning and task type on second language performance. Studies in Second Language Acquisition, 18(3), 299-323. https://doi.org/10.1017/S0272263100015047

Graesser, A. C., Golding, J. M., \& Long, D. L. (1991). Narrative representation and comprehension. In R. Barr, M. L. Kamil, P. B. Mosenthal \& P. D. Pearson (Eds.), Handbook of reading research (Vol. 2, pp. 171-205). Hillsdale, NJ: Erlbaum.

Huh, M. H., \& Lee, J. (2018). Task Complexity and Writing Prompts and Performance in EFL High School Students' Narrative Writing. English Teaching, 73(4). https://doi.org/10.15858/engtea.73.4.201812.55

Kadel, P. B. (2018). Effectiveness of task-based language teaching in developing writing skills at the secondary level in Nepal. Doctoral dissertation. Retrieved from http://hdl.handle.net/123456789/280

Kafipour, R., Mahmoudi, E., \& Khojasteh, L. (2018). The effect of task-based language teaching on analytic $\begin{array}{lllll}\text { writing in } & \text { EFL classrooms. Cogent } & \text { Education, } & \text { 5(1), }\end{array}$ https://doi.org/10.1080/2331186X.2018.1496627

Kareem, M. N. (2013). An investigation study of academic writing problems faced by Arab postgraduate students at Universiti Teknologi Malaysia (UTM). Theory and Practice in Language Studies, 3(9), 15-52. https://doi.org/10.4304/tpls.3.9.1552-1557

Karim, I. T., Husain, D., \& Weda, S. (2014). The Implementation of Task-Based Language Teaching (TBLT) to Improve Students' Ability in Writing Narrative Text. Prosiding, 1(1), 63-70. Retrieved from http://www.journal.uncp.ac.id/index.php/proceding/article/view/224

Kim, Y., \& Kim, J. (2005). Teaching Korean university writing class: Balancing the process and the genre approach. Asian EFL Journal, 7(2), 1-15. Retrieved from https://www.asian-efl-journal.com/main-journals/teaching-korean-university-writing-class-balancing-the-pr ocess-and-the-genre-approach/ 
Lee. J. (2000). Tasks and Communicating in Language Classrooms. Boston, USA: McGraw-Hill.

Lewin, K. (1946). Action research and minority problems. Journal of Social Issues, 2(4), 34-46. https://doi.org/10.1111/j.1540-4560.1946.tb02295.x

Lingley, D. (2006). A task-based approach to teaching a content-based Canadian studies course in an EFL context. The Asian EFL Journal Quarterly, 8(3), 122-139. Retrieved from https://www.asian-efl-journal.com/main-journals/a-task-based-approach-to-teaching-a-content-based-canadi an-studies-course-in-an-efl-context/

Long, M. (1985). A role for Instruction in Second Language Acquisition: Task-Based Language Teaching. In K. Hystelstam \& M. Pienemann (Eds.), Modeling and Accessing Second Language Acquisition. Cleverdon, UK: Multilingual Matters.

Long, M. (1991). Focus on form: A Design Feature in Language Teaching Methodology. In K. de Bot, R. Ginsburg \& C. S. Kramsch (Eds.), Foreign Language Research in Cross Cultural Perspectives (pp. 39-52). Amsterdam, Netherlands: John Benjamin. https://doi.org/10.1075/sibil.2.07lon

Long, M. (1997). Focus on Form in Task-Based Language Teaching. Fourth Annual. McGraw-Hill Satellite Teleconference. Retrieved from http://www.mhhe.com/socscience/foreignlang/top/htm

Long, M. (2005, September). TBLT: Building the Road as We Travel (pp. 21-23). Plenary Address Delivered at the International Conference on Task-Based Language Teaching. Leuven, Belgium.

Long, M., \& Crookes, G. (1992). Three approaches to task-based syllabus design. TESOL Quarterly, 26(1), $27-$ 56. https://doi.org/10.2307/3587368

Long, M. H. (1985). A role for instruction in second language acquisition: Task-based language teaching. In K. Hyltenstam \& M. Pienemann (Eds.), Modeling and accessing second language acquisition (pp. 77-99). Clevedon: Multilingual Matters.

Maxwell, J. A. (1996). Qualitative research design. Newbury Park, CA: Sage.

Maxwell, J. A. (1996a). Qualitative research design: An interactive approach. Thousand Oaks, CA: Sage.

Narjess, A. T., \& Sayyed, M. A. (2013). A comparative study of the effects of task-based writing under different pre-task planning conditions on Intermediate EFL learners' written performance in personal and decision-making tasks. International Research Journal of Applied and Basic Sciences, 5(8), 970-978. Retrieved from https://pdfs.semanticscholar.org/943a/c9f900fe8d1266b07ea9d2a656f1e06b75e1.pdf

Nunan, D. (1989). Designing Tasks for the Communicative Classroom. Cambridge: Cambridge University Press.

Nunan, D. (2004). Task-Based Language Teaching. Cambridge: Cambridge University Press. https://doi.org/10.1017/CBO9780511667336

Prabhu, N. S. (1987). Second Language Pedagogy. Oxford: Oxford University Press.

Prabhu, N. S. (1987a). Language education, equipping or enabling. In B. K. Das (Ed.), Language Education in Human Resource Development (Anthology Series 20). Singapore: RELC.

Pragasam, J. A., Singh, C. K. S., Singh, T. S. M., Mostafa, N. A., Ja'afar, H., Abdullah, M. S., ... Khaja, F. N. M. (2018). The Use of Task-Based Learning (TBL) to Improve form Four Students' Performance in Narrative Writing. International Journal of Academic Research in Progressive Education and Development, 7(3), 4859.

Rahman, T. (1996). Language and Politics in Pakistan Karachi. Oxford University Press.

Rashid, M. (2017). Exploring the Effectiveness of Task Based Language Teaching in the Improvement of Master Level Students' Narrative Writing Skill. The Journal of Social Sciences Research, 3(3), 20-27. Retrieved from https://ideas.repec.org/a/arp/tjssrr/2017p20-27.html

Ratnawati, R. (2019). The Implementation Olof Task Based Learning in Teaching Writing in State Vocational High School 7 Bone. Doctoral dissertation, Universitas Negeri Makassar. Retrieved from http://eprints.unm.ac.id/id/eprint/14864

Rehman, K. A., \& Muhammad Z. S. (2015). The Effectiveness of English Language Learning in Multilingual Schools in Pakistan. In Language and Social Cohesion in the Developing World (pp. 116-127). Colombo: British Council and Deutsche Gesellschaft fur Intemationale Zusammenarbeit (GIZ).

Rehman, K. A., \& Sagar, M. Z. (2015). The effectiveness of English language learning in multilingual schools in 
Pakistan. Language and Social Cohesion in the Developing World, 116-127.

Richards, J. C., \& Schmidt, R. (2002). Longman Dictionary of Language Teaching and Applied Linguistics (3rd ed.). Peason Education Limited.

Richard, J. C., \& Theodore, S. R. (2001). Approaches and Methods in Language Teaching (2nd ed.). Cambridge: Cambridge University Press.

Rubaiat, S. (2018). The effectiveness of task-based language teaching in improving ESL learners' reading and writing skills. Doctoral dissertation, BRAC University. Retrieved from http://hdl.handle.net/10361/10790

Salaberry, R. (2001). Task-Sequencing in L2 Acquisition. Texas Papers in Foreign Language Education, 6(1), 101-112.

Sanchez, A. (1992). Historia de la ensenanza del espanolcomolenguaextranjera. Madrid: SGEL.

Sanchez, A. (1997). Los metodos en la ensenanza de idiomas. Evolucionhistorica y analisisdidactico. Madrid: SGEL.

Sanchez, A. (2004). The Task-based Approach in Language Teaching. International Journal of English Studies, 4(1), 39-71.

Seyyedi, K., Ismail, S. A. M. M., Orang, M., \& Nejad, M. S. (2013). The Effect of Pre-Task Planning Time on L2 Learners' Narrative Writing Performance. English Language Teaching, 6(12), 1-10. https://doi.org/10.5539/elt.v6n12p1

Seyyedi, K., Ismail, S., \& Mohamed, A. (2014). The Effect of Task Structure on Second Language Learner's Narrative Writing Performance. Journal of Foreign Languages, Cultures and Civilizations, 2(1), 41-53.

Skehan, P. (1996). A framework for the implementation of task-based instruction. Applied Linguistics, 17(1), 3862. https://doi.org/10.1093/applin/17.1.38

Skehan, P. (1998). Task-based instruction. Annual Review of Applied Linguistics, 18, $268-286$. https://doi.org/10.1017/S0267190500003585

Skehan, P. (1998a). A Cognitive Approach to Language Learning. Oxford, UK: Oxford University Press.

Skehan, P. (2003). Task-Based Instruction. Cambridge, UK: Cambridge University Press. https://doi.org/10.1017/S026144480200188X

Sofia, H. (2013). Employing task-based approach to teach technical writing for students of engineering using Web 2.0 tools. International Journal of English and Literature, 3(5), 7-20. Retrieved from https://www.researchgate.net/publication/259006035_Employing_task_based_approach_to_teach_technical _writing_to_students_of_engineering

Tangpermpoon, T. (2008). Integrated approaches to improve students writing skills for English major students. ABAC Journal, 28(2), $\quad$ Retrieved $1-9$ from http://www.abacjournal.au.edu/2008/may08/01(1-9)_article01.pdf

Tri, P., \& Fithriyah, N. H. (2017). The Implementation of Teaching Writing Narrative Text by Using Task-Based Instruction at VIII Grade Students of SMP Muhammadiyah 1 Gatak in 2015/2016 Academic Year. Doctoral dissertation, IAIN Surakarta. $\quad$ Retrieved from http://eprints.iain-surakarta.ac.id/749/1/Tri\%20Prasetyawati.pdf

Vygotsky, L. S. (1962). Thought and Language. Cambridge, Mass: MIT Press. https://doi.org/10.1037/11193-000

Vygotsky, L. S. (1978). Mind in Society: The Development of Higher Psychological Processes. Cambridge, Mass: Harvard University Press.

Willis, J. (1996). A framework for task-based learning. Longman Handbooks for Language Teachers. London: Longman.

Willis, J. (1996a). A Flexible Framework for Task-Based Learning. In J. Willis \& D. Willis (Eds.), Challenge and Change in Language Teaching (pp. 52-62). Heinemann.

Willis, J. (1998). Task-Based Learning? What Kind of Adventure? Retrieved December 25, 2019 from http://langue.hyper.chubu.ac/jp/jalt/pub/tlt/98/jul/willis.html

Zaki, S., Rashidi, Z., \& Hussain, K. H. (2013). Improving Instructional practices: where to begin? Journal of Research \& Reflections in Education, 7(1), 65-76. Retrieved from https://www.researchgate.net/profile/Sajida_Zaki/publication/310331964_Improving_Instructional_Practice 
s_Where to Begin_Journal_of Research_and Reflections_in_Education_Vol7_No_1June 2013 pp_65-76 /links/58318af408ae 004f74c2782a/Improving-Instructional-Practices-Where-to-Begin-Journal-of-Researchand-Reflections-in-Education-Vol7-No-1 June-2013-pp-65-76.pdf

\section{Appendix A}

\section{Narrative Essay Writing Worksheets}

Task No. 1: Identify the Elements of Narrative Essay in the Following Pictures.

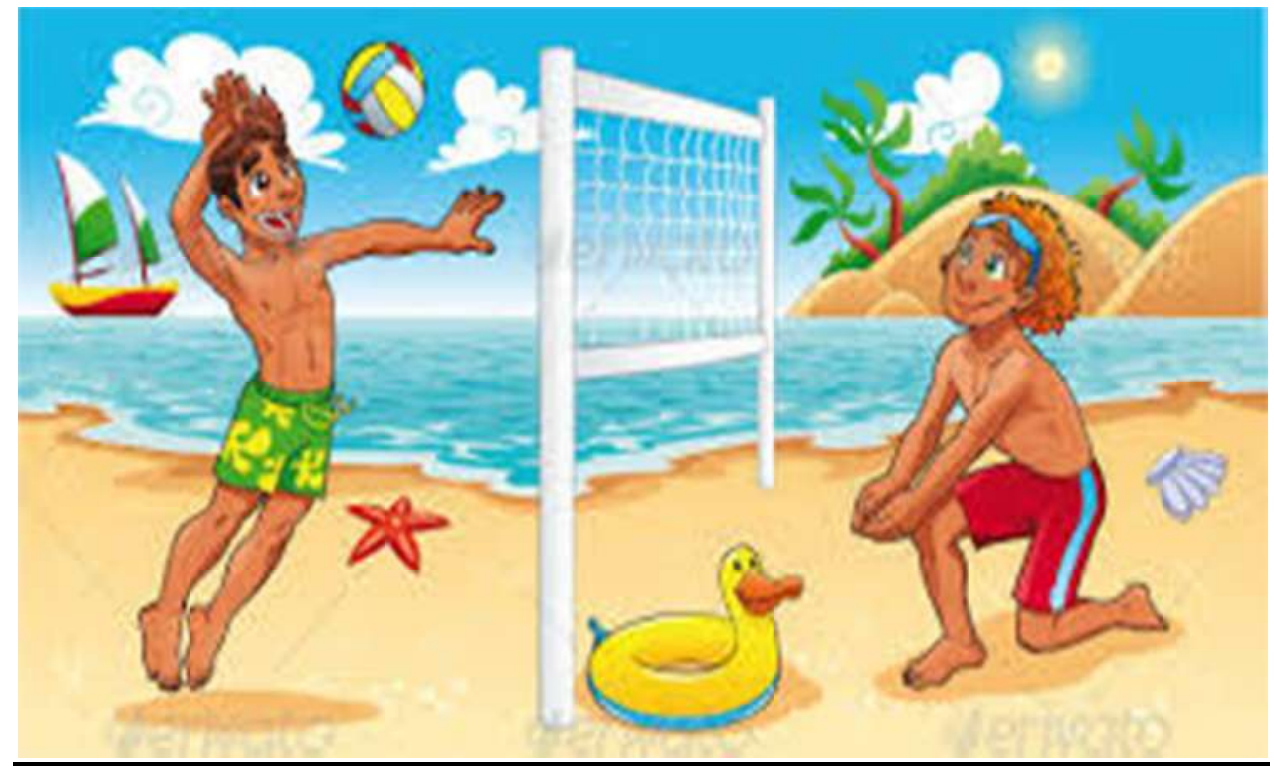

Figure 2

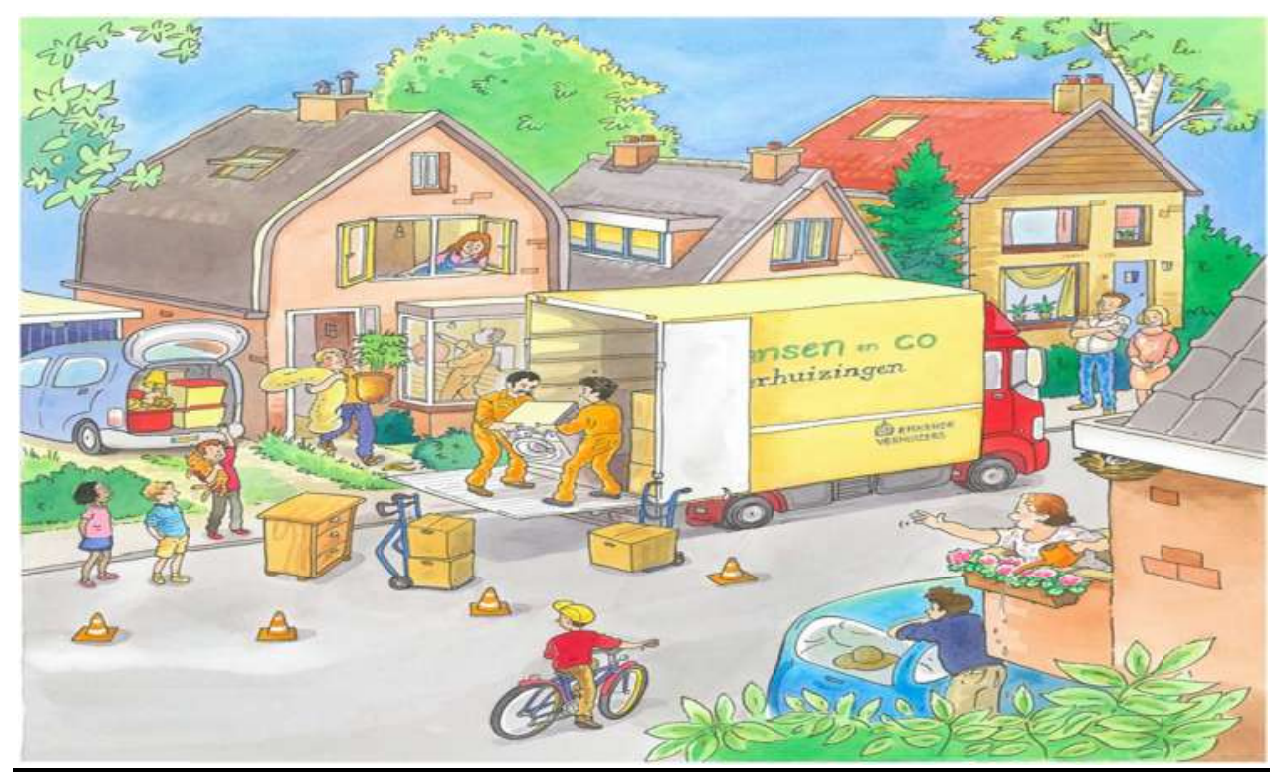

Figure 3 


\section{Appendix B}

Task No. 2: Write a Narrative based on the following prompt.

\section{Prompt:}

Imagine that your friend has a great tree house. There is only one problem. The key is missing!

Writing Task:

Write a story about how you and your friend solve the problem. Make sure to fill in missing information. It's a good idea to include details, interesting words, and dialogue. You have 50 minutes.

\section{Appendix C}

Task No. 3: Write a narrative essay on "My First Day at the University."

\section{Appendix D}

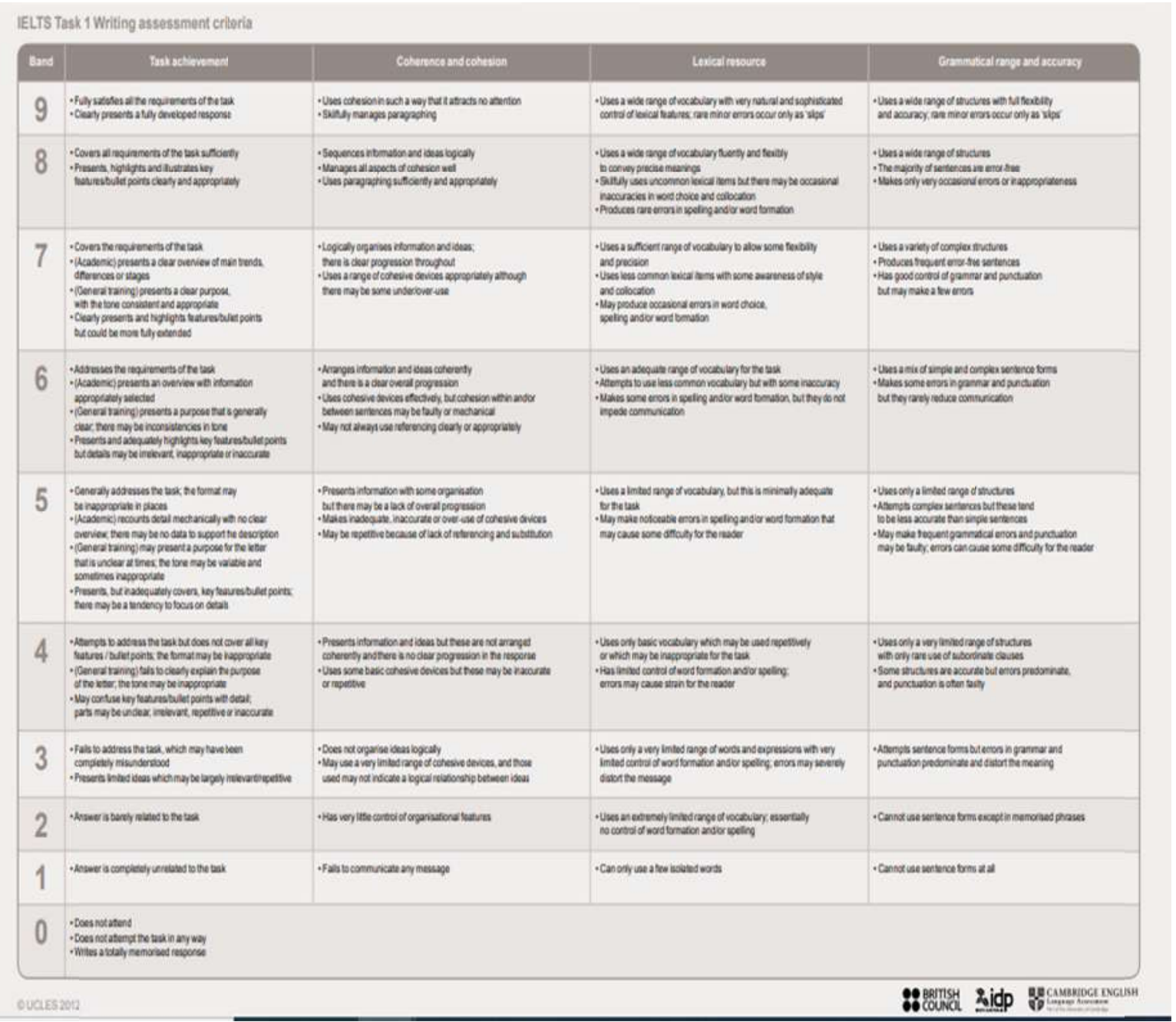

Figure 4. IELTS writing band descriptor (2015) 


\section{Appendix E}

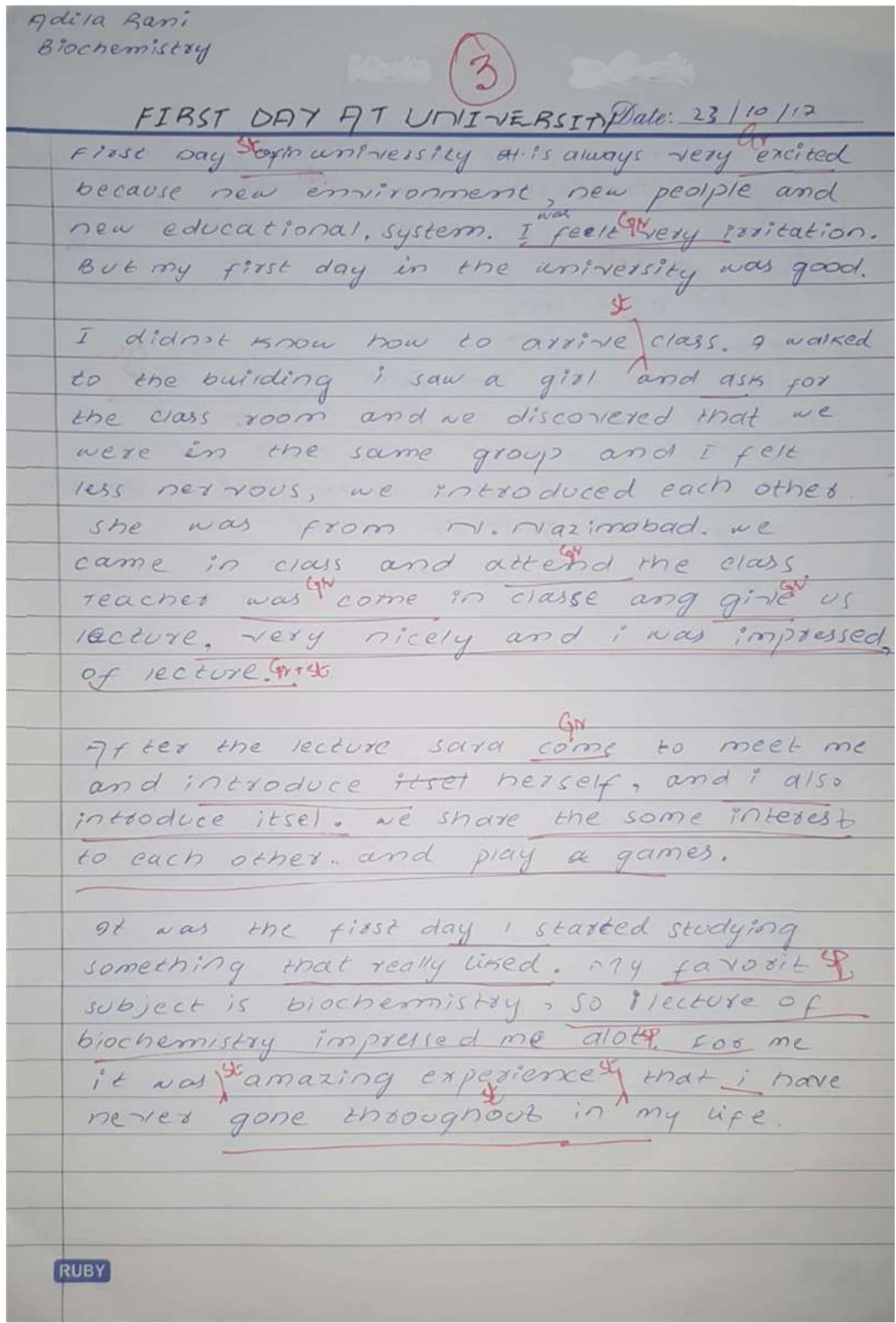

Figure 5. Writing sample 1.1 


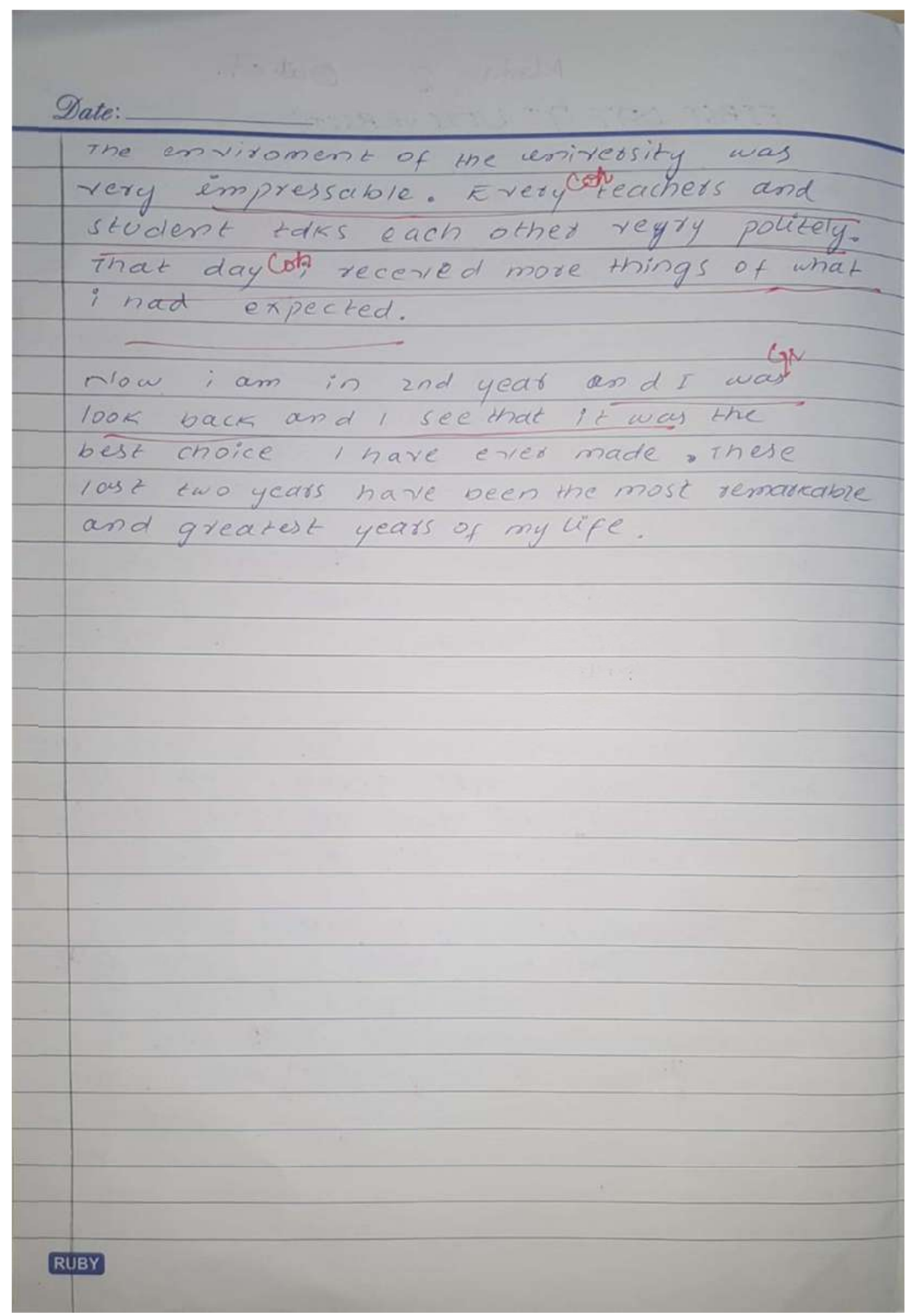

Figure 6. Writing sample 1.2 


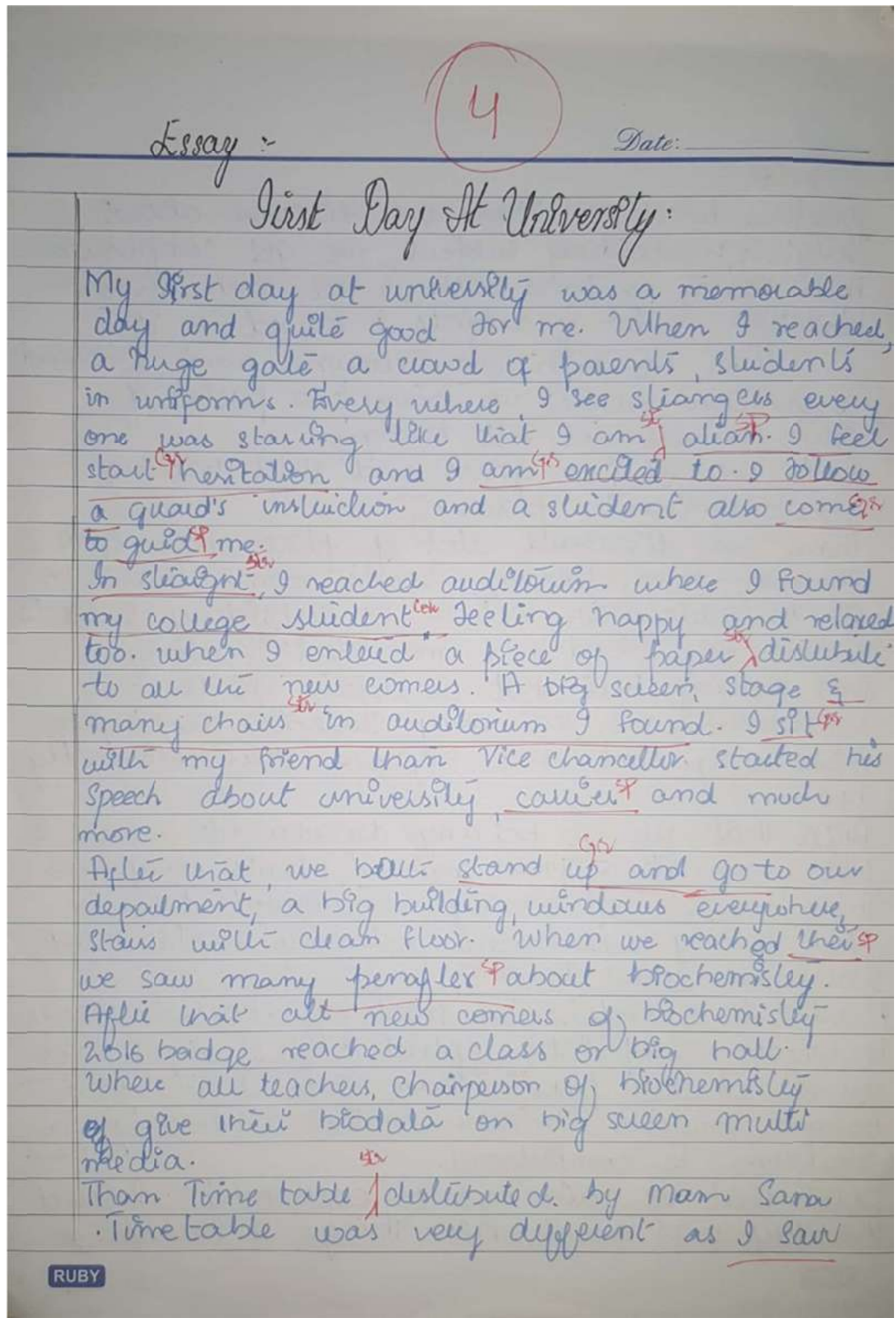

Figure 7. Writing sample 2.1 


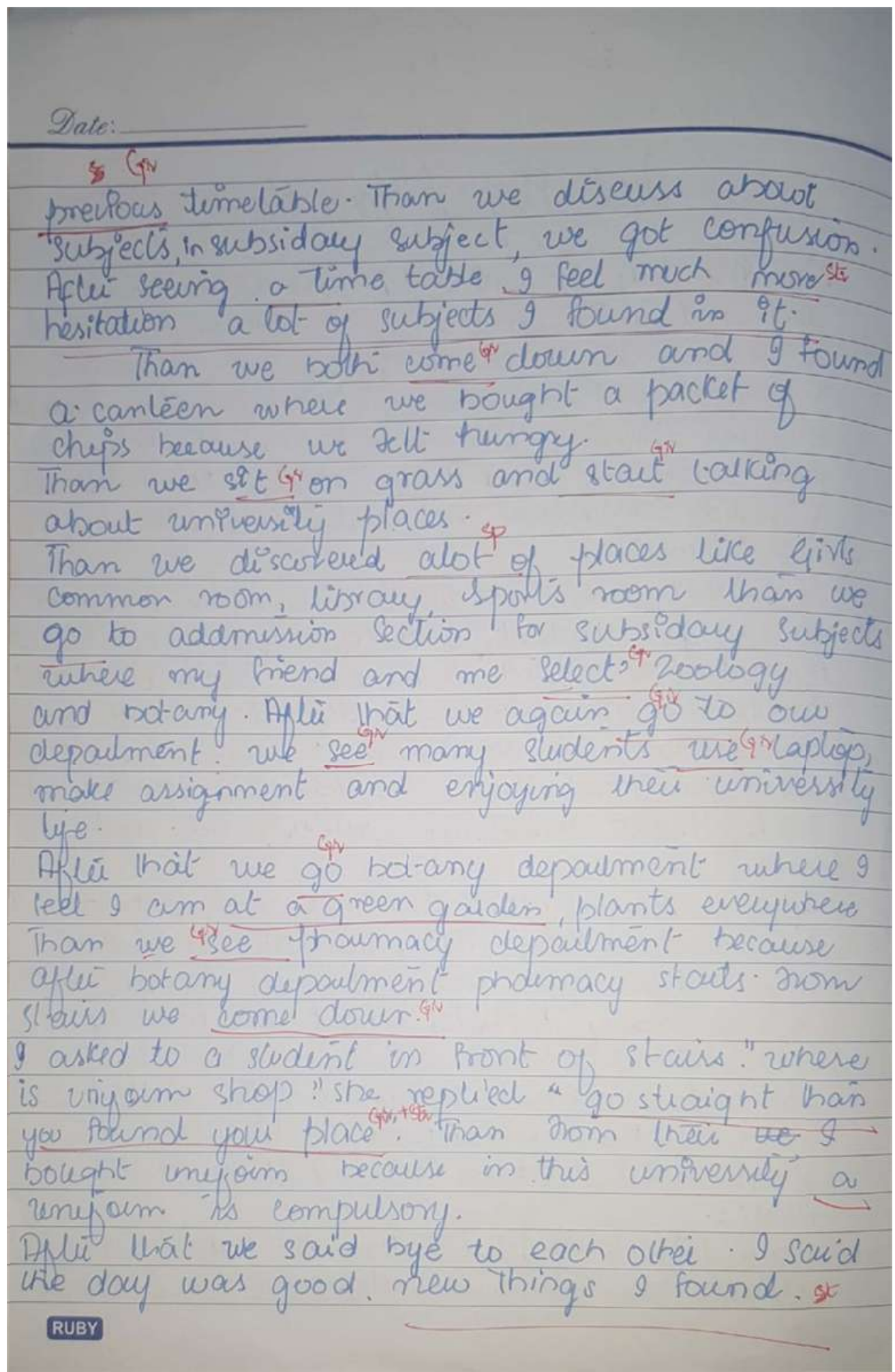

Figure 8 . Writing sample 2.2 


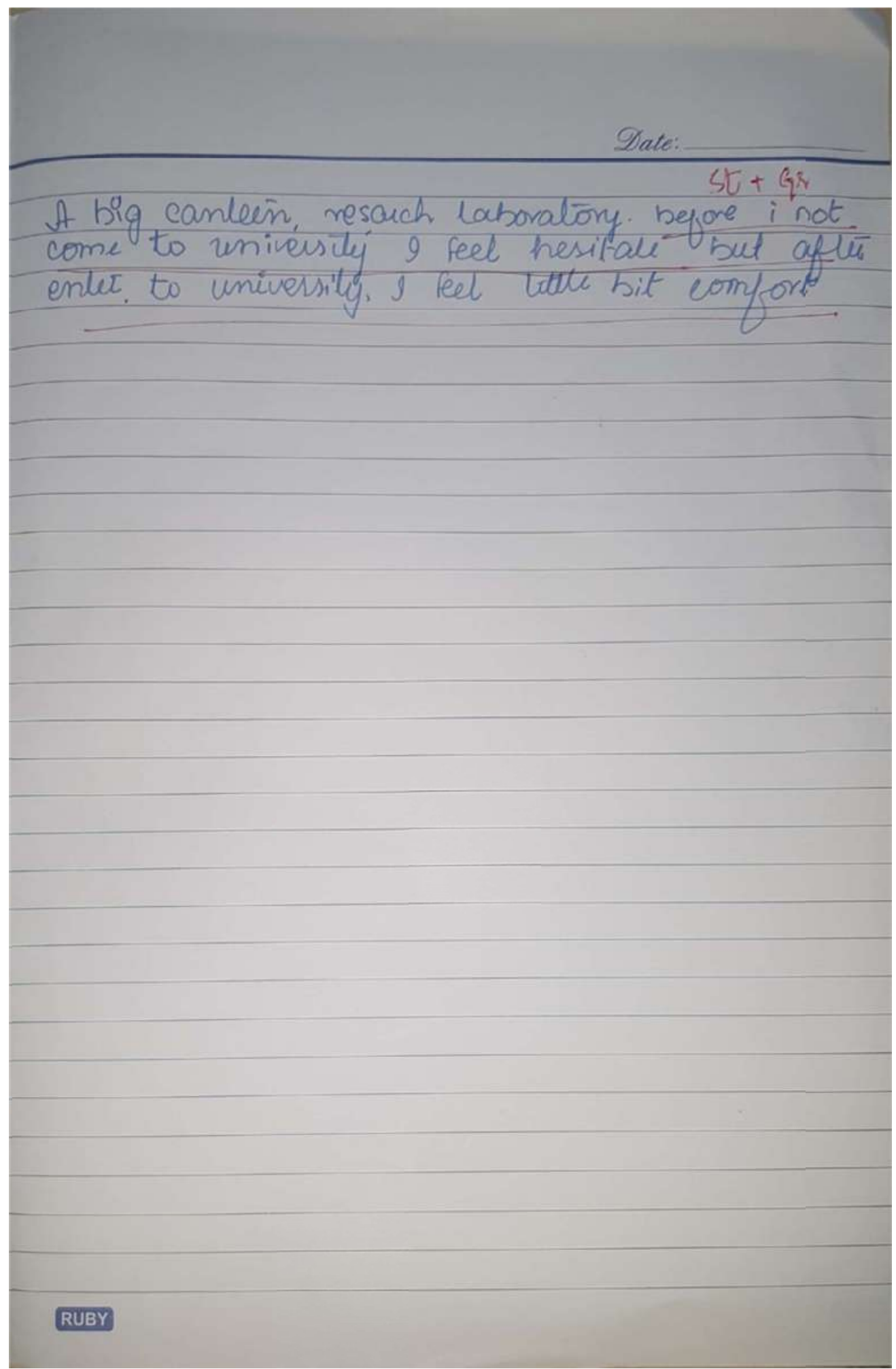

Figure 9. Writing sample 2.3 


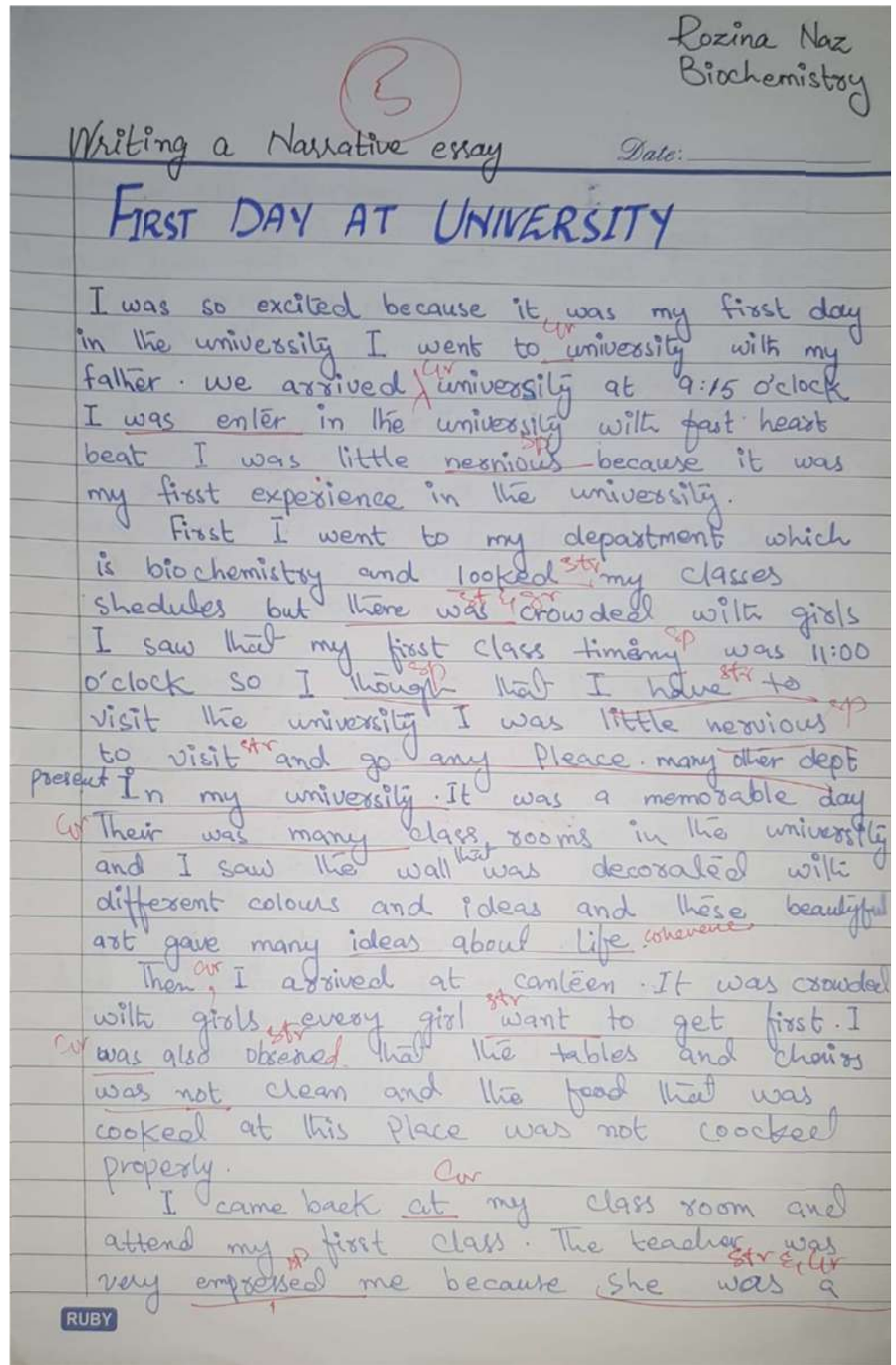

Figure 10. Writing sample 3.1 


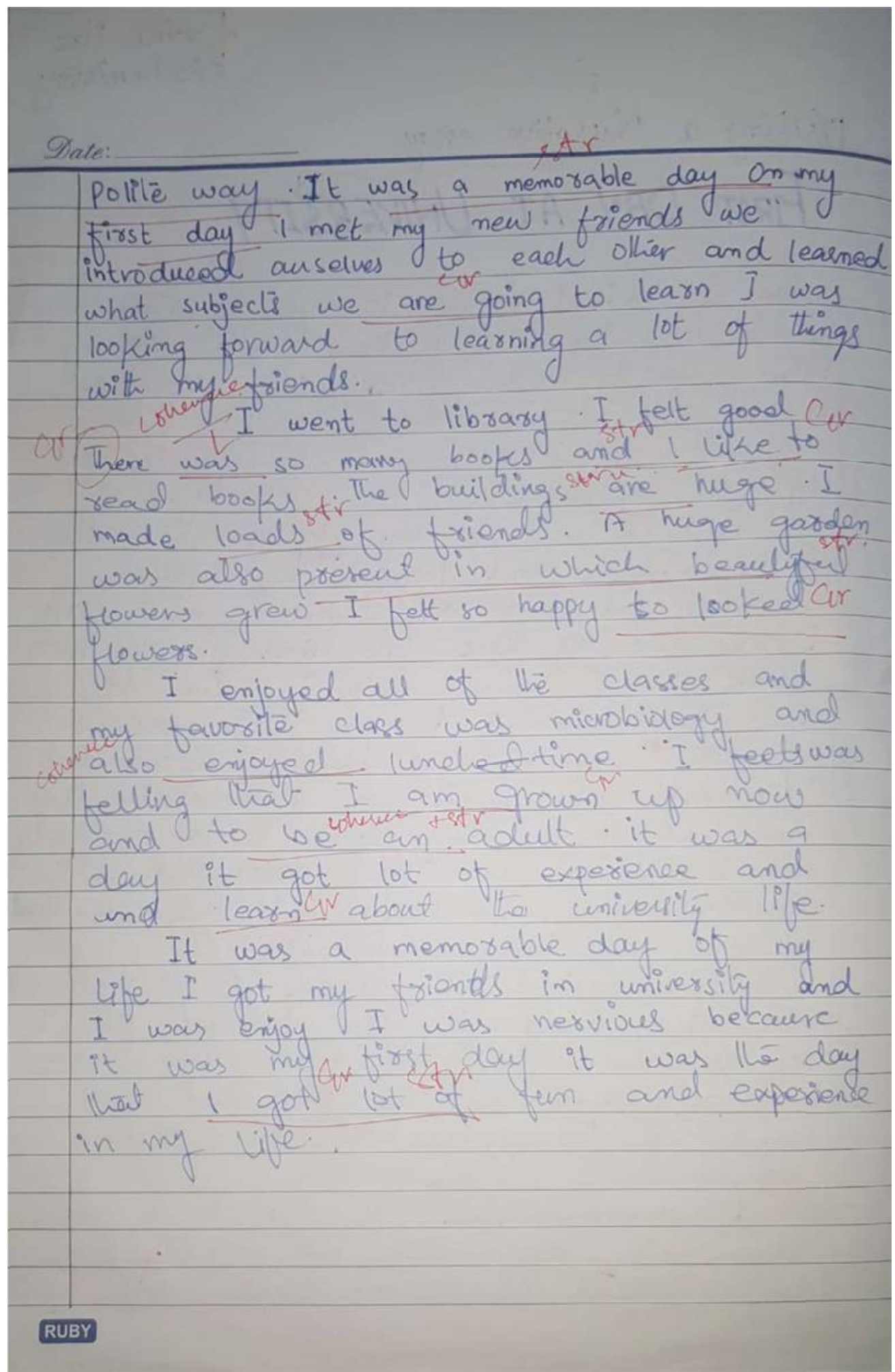

Figure 11. Writing sample 3.2 


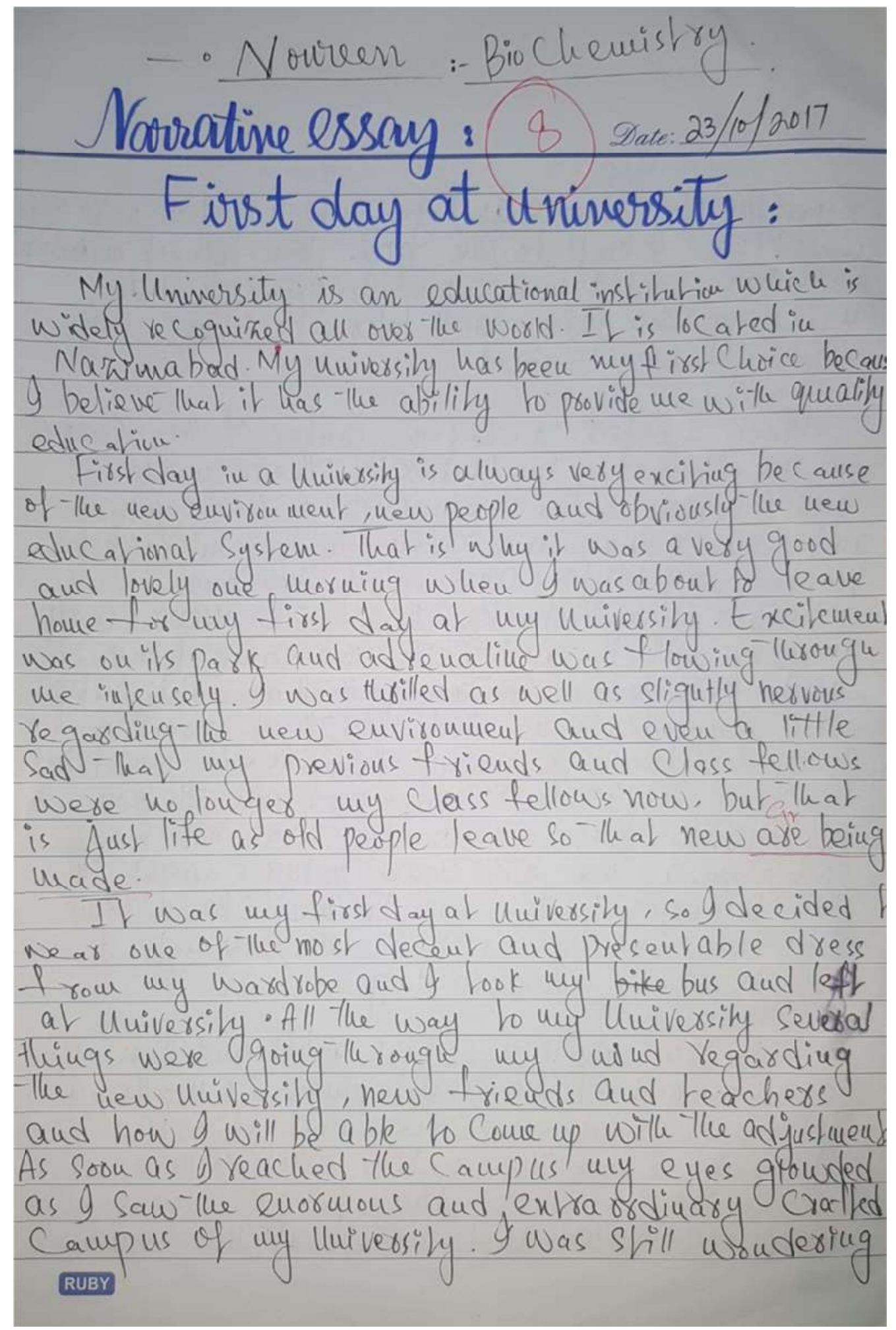

Figure 12. Writing sample 4.1 


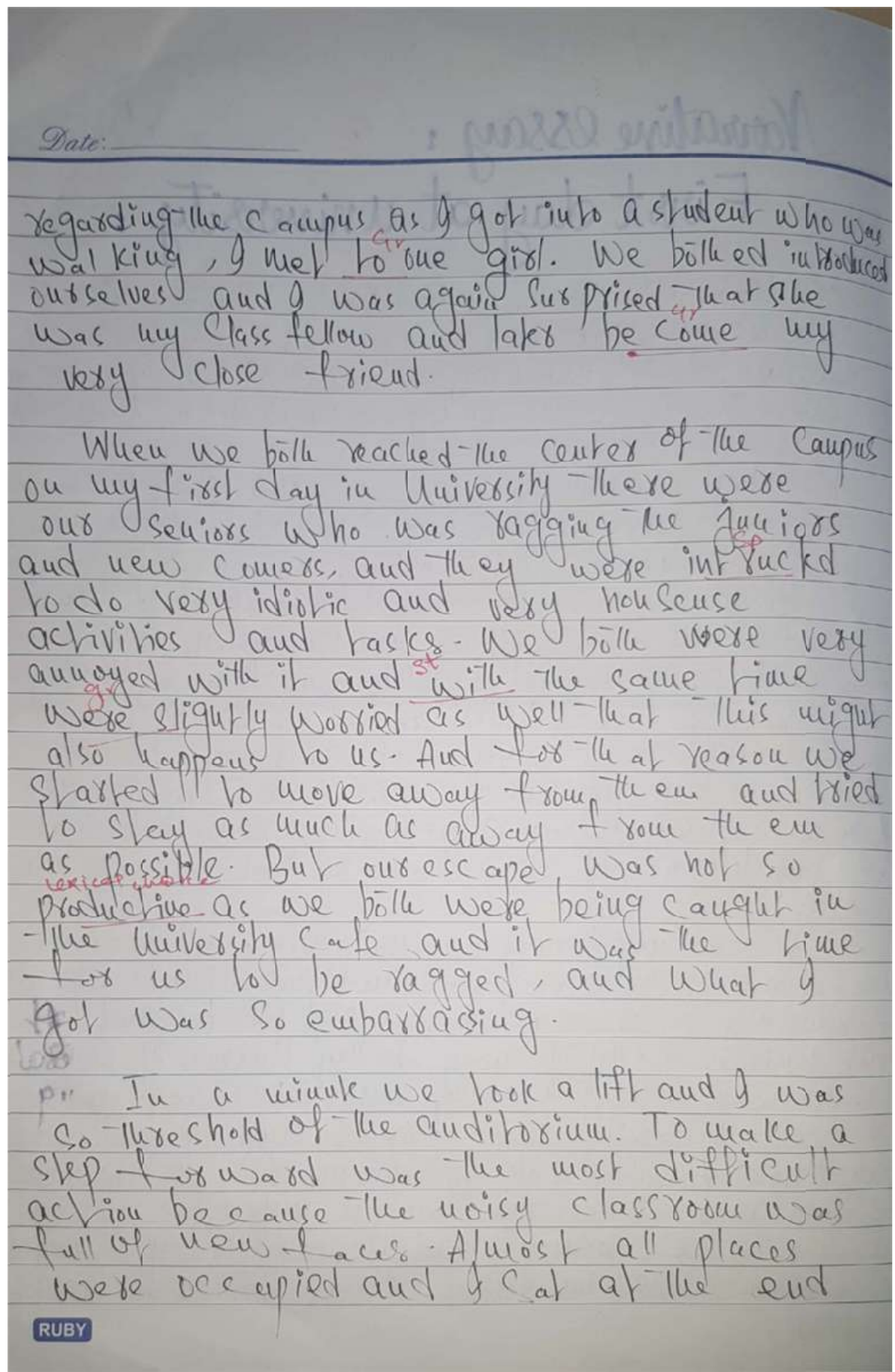

Figure 13. Writing sample 4.2 


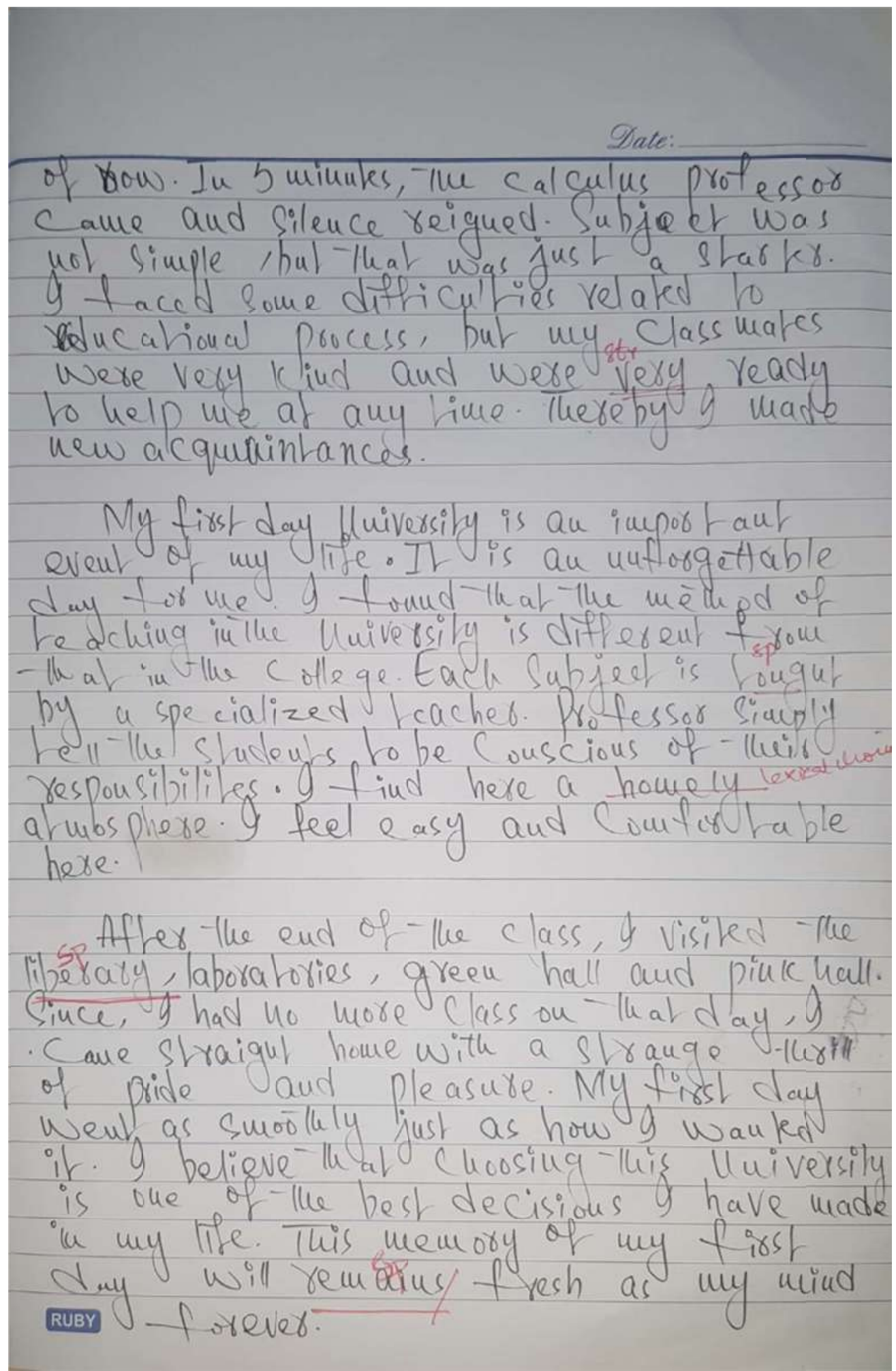

Figure 14. Writing sample 4.3

\section{Copyrights}

Copyright for this article is retained by the author, with first publication rights granted to the journal.

This is an open-access article distributed under the terms and conditions of the Creative Commons Attribution license (http://creativecommons.org/licenses/by/4.0/). 